\title{
COL4A2 Gene Product
}

National Cancer Institute

\section{Source}

National Cancer Institute. COL4A2 Gene Product. NCI Thesaurus. Code C152983.

A protein encoded by the COL4A2 gene. 